\title{
ANALISIS PENILAIAN KINERJA KEUANGAN PERUSAHAAN MENGGUNAKAN RASIO KEUANGAN PADA PT UNILEVER INDONESIA TBK YANG TERDAFTAR DI BURSA EFEK INDONESIA (BEI)
}

\author{
Dedi Suhendro \\ AMIK Tunas Bangsa Pematangsiantar, Sumatera Utara-Indonesia \\ dedi.su@amiktunasbangsa.ac.id atau didihendra5@ymail.com
}

\begin{abstract}
The purpose of this study to determine the financial performance of PT Unilever Indonesia Tbk 2010-2015 period. Financial ratios used: Liquidity Ratios, Asset Management Ratios, Debt Management Ratios and Profitability Ratios. The results of the research liquidity ratio, Current ratio and Quick Ratio decreased which indicates the liquidity of the company is not good and in fulfilling its smooth liability has not been said good. The ratio of asset management increases overall, because the company is already efficient in the use of assets to create sales that will increase the company's profit. The ratio of debt management, total debt to total assets is good enough because the company is able to cover its debt through its own capital and able to cover the interest expense with the funds owned. Profitability ratios show poor performance because the net profit of each sale is decreasing. Lack of efficiency in performance in optimizing their own capital to generate net income but using its assets productively increased so the profits derived by companies based on investments invested in the company is good enough.
\end{abstract}

Keywords: PT Unilever Tbk, Liquidity Ratio, Asset Management Ratio, Debt Management Ratio and Profitability Ratio

\begin{abstract}
Abstrak
Tujuan dari penelitian ini untuk mengetahui kinerja keuangan pada PT Unilever Indonesia Tbk periode 2010-2015. Rasio keuangan yang digunakan: Rasio Likuiditas, Rasio Manajemen Aset, Rasio Manajemen Utang dan Rasio Profitabilitas. Hasil penelitian rasio likuiditas, Current ratio dan Quick Ratio menurun yang menandakan likuiditas perusahaan kurang baik dan dalam memenuhi kewajiban lancarnya belum dikatakan baik. Rasio manajemen aset meningkat secara keseluruhan, disebabkan perusahaan sudah efisien dalam penggunaan asetnya untuk menciptakan penjualan yang akan meningkatkan laba perusahaan. Rasio manajemen utang, total utang terhadap total aktiva sudah cukup baik karena perusahaan mampu menutup utangnya melalui modal sendiri dan mampu menutupi beban bunga dengan dana yang dimiliki. Rasio profitabilitas menunjukkan kinerja kurang baik karena laba bersih setiap penjualan yang diperoleh semakin menurun. Kurang efisiensinya kinerja dalam mengoptimalkan modal sendiri untuk menghasilkan laba bersih tetapi menggunakan aktivanya secara produktif semakin meningkat dengan demikian keuntungan yang diperoleh perusahaan berdasarkan investasi yang ditanamkan pada perusahaaan cukup baik.
\end{abstract}


Analisis Penilaian Kinerja Keuangan Perusahaan Menggunakan Rasio 483

Keuangan Pada PT Unilever Indonesia Tbk Yang Terdaftar

Di Bursa Efek Indonesia (Dedi Suhendro)

Kata Kunci: PT Unilever Tbk, Rasio Likuiditas, Rasio Manajemen Aset, Rasio Manajemen Utang dan Rasio Profitabilitas

\section{Pendahuluan}

Laporan keuangan merupakan daftar untuk mengetahui jumlah kekayaan perusahaan pada periode tertentu, dalam bentuk neraca dan laporan laba rugi. ${ }^{1}$ Sedangkan menurut penelitian Hendry Andres Maith Laporan keuangan merupakan salah satu informasi yang sangat penting dalam menilai perkembangan perusahaan, dapat juga digunakan untuk menilai prestasi yang dicapai perusahaan pada saat lampau, sekarang dan rencana pada waktu yang akan datang. ${ }^{2}$ Dapat disimpulkan bahwa laporan keuangan merupakan salah satu produk akhir dari suatu proses akuntansi yang bersifat kuantitatif dan digunakan sebagai alat bantu manajemen dalam pengambilan keputusan, baik bagi pihak intern yaitu manajer, maupun pihak ekstern yaitu kreditur, investor dan pemerintah. Bagi pihak intern, laporan keuangan digunakan sebagai alat pertanggungjawaban manajemen kepada pemegang saham, dan sekaligus menggambarkan tingkat pemberian kredit. Bagi pemerintah, laporan keuangan biasanya digunakan sebagai alat untuk keberhasilan kebijakan ekonomi atau sebagai landasan untuk menetapkan kebijakan lain. Agar dapat menggunakan laporan keuangan tersebut sebagai alat yang mendasari keputusan, memerlukan suatu pengukuran-pengukuran tertentu, dimana pengukuran tersebut menggunakan analisis laporan keuangan yang terdiri dari Likuiditas, Manajemen aset, Manajemen Utang, dan Profitabilitas.

Tujuan laporan keuangan yaitu untuk menyediakan informasi yang berkaitan dengan posisi keuangan, prestasi (hasil usaha) perusahaan serta perubahan posisi keuangan suatu perusahaan yang bermanfaat bagi pemakai dalam pengambilan keputusan ekonomi. ${ }^{3}$ Tujuan Laporan Keuangan dalam penelitian Mutiara Nur' Rahmah dan Euis Komariah untuk memberikan informasi keuangan suatu perusahaan, baik pada saat tertentu maupun pada periode tertentu, yang disusun secara mendadak maupun secara berkala, serta mampu memberikan informasi keuangan kepada pihak dalam dan luar perusahaan yang memiliki kepentingan terhadap perusahaan. ${ }^{4}$ Tujuan laporan keuangan menurut Ikatan Akuntan Indonesia adalah memberikan informasi mengenai posisi keuangan, kinerja keuangan dan arus kas entitas yang bermanfaat bagi sebagian besar 
kalangan pengguna laporan keuangan dalam pembuatan keputusan ekonomi. Laporan keuangan juga menunjukkan hasil pertanggungjawaban manajemen atas penggunaan sumber daya yang dipercayakan kepada mereka. ${ }^{5}$

Penilaian terhadap kondisi perusahaan atas usaha manajemen dalam melaksanakan fungsinya dalam suatu periode tertentu merupakan kinerja keuangan dan laporan keuangan media yang digunakan dalam menilai kinerja keuangan sehingga laporan keuangan merupakan hasil akhir dari proses akuntansi yang menunjukkan kondisi perusahaan saat ini sebagai media komunikasi antara data keuangan maupun aktivitas perusahaan bagi pihak yang berkepentingan guna pengambilan keputusan pada periode tertentu.

Untuk mendapatkan informasi mengenai kinerja perusahaan dari laporan keuangan, maka perlu dilakukan analisis laporan keuangan. Analisis laporan keuangan sangat penting bagi kelangsungan dan perkembangan perusahaan, terutama dalam menghadapi iklim kompetisi yang semakin ketat. Dalam melakukan analisis laporan keuangan dapat dilakukan dengan menganalisis setiap rasio keuangan yang ada. Secara umum terdapat empat rasio keuangan yakni rasio likuiditas, rasio manajemen aset, rasio manajemen utang dan rasio profitabilitas.

Salah satu rasio yang dapat digunakan untuk menilai kinerja keuangan adalah rasio profitabilitas, karena rasio profitabilitas merupakan hasil bersih dari serangkaian kebijakan dan keputusan yang menunjukkan pengaruh gabungan dari likuiditas, manajemen aset, dan utang terhadap hasil operasi. Dapat disimpulkan bahwa rasio profitabilitas mencerminkan hasil akhir dari kebijakan keuangan dan keputusan operasional. Rasio profitabilitas juga menggambarkan efektifitas dan efisiensi perusahaan dalam melaksanakan kegiatan operasionalnya dengan menggunakan seluruh modal yang dimiliki baik aset maupun modal sendiri sehingga menghasilkan laba untuk kesinambungan hidup perusahaan. Berdasarkan paparan tersebut maka penelitian ini menggunakan rasio profitabilitas sebagai alat ukur menilai kinerja keuangan.

Analisis rasio profitabilitas digunakan untuk melihat sejauh mana perusahaan melakukan efektivitas pengelolaan manajemen dan keuangan. Rasio profitabilitas dapat diukur dengan Net Profit Margin (NPM), Return On Asset (ROA) dan Return On Equity (ROE).

Net Profit Margin (NPM), yaitu rasio atau perbandingan antara laba bersih yang telah dicapai dengan tingkat penjualan. Semakin tinggi skala rasio NPM, 
maka hal ini akan menunjukkan bahwa perusahaan semakin efisien dalam menjalankan operasinya. ${ }^{6}$ Return On Equity (ROE), menunjukkan kemampuan perusahaan untuk menghasilkan laba setelah pajak dengan menggunakan modal sendiri yang dimiliki perusahaan. Rasio ini penting bagi pemegang saham untuk mengetahui efektivitas dan efisiensi pengelolaan modal sendiri yang dilakukan oleh pihak manajemen perusahaan. ${ }^{7}$ Return On Asset (ROA), menunjukkan kemampuan perusahaan dengan menggunakan seluruh aktiva yang dimiliki untuk menghasilkan laba setelah pajak. Rasio ini penting bagi pihak manajemen untuk mengevaluasi efektivitas dan efisiensi manajemen perusahaan dalam mengelola seluruh aktiva perusahaan. ${ }^{8}$

Sebagai perusahaan manufaktur terkemuka, PT Unilever Indonesia Tbk merupakan perusahaan yang sangat maju, berkembang dan terdaftar di Bursa Efek Indonesia (BEI). Penelitian ini dilakukan untuk mengetahui kinerja keuangan perusahaan dengan menganalisis laporan keuangan menggunakan analisis rasio keuangan pada PT Unilever Indonesia Tbk. Sehingga dapat dikatakan rasio profitabilitas merupakan gambaran kinerja keuangan perusahaan PT Unilever Indonesia Tbk yang terdaftar di Bursa Efek Indonesia (BEI). Berdasarkan uraian di atas, peneliti memberikan judul dalam penelitian ini yaitu: "Analisis penilaian kinerja keuangan perusahaan menggunakan rasio keuangan pada PT Unilever Indonesia Tbk yang terdaftar di Bursa Efek Indonesia (BEI).

Tabel 1. Rasio Profitabilitas PT Unilever Indonesia, Tbk Periode 2010-2015

\begin{tabular}{|c|c|c|c|c|}
\hline No & Tahun & $\begin{array}{c}\text { Net Profit Margin } \\
(\text { NPM) }(\%)\end{array}$ & $\begin{array}{c}\text { Return On Asset } \\
\text { (ROA) }(\%)\end{array}$ & $\begin{array}{c}\text { Return On Equity } \\
(\text { ROE) }(\%)\end{array}$ \\
\hline 1 & 2010 & 17,18 & 38,89 & 83,59 \\
\hline 2 & 2011 & 17,74 & 39,72 & 113,13 \\
\hline 3 & 2012 & 17,72 & 40,37 & 121,94 \\
\hline 4 & 2013 & 17,40 & 40,10 & 125,80 \\
\hline 5 & 2014 & 16,62 & 40,18 & 120,89 \\
\hline 6 & 2015 & 16,03 & 37,20 & 121,22 \\
\hline & Rata-Rata & $\mathbf{1 1 7 , 1 1 5}$ & $\mathbf{3 9 , 4 1}$ & $\mathbf{1 1 4 , 4 2 8}$ \\
\hline
\end{tabular}

Sumber: Data diolah dari laporan keuangan PT Unilever Indonesia Tbk 


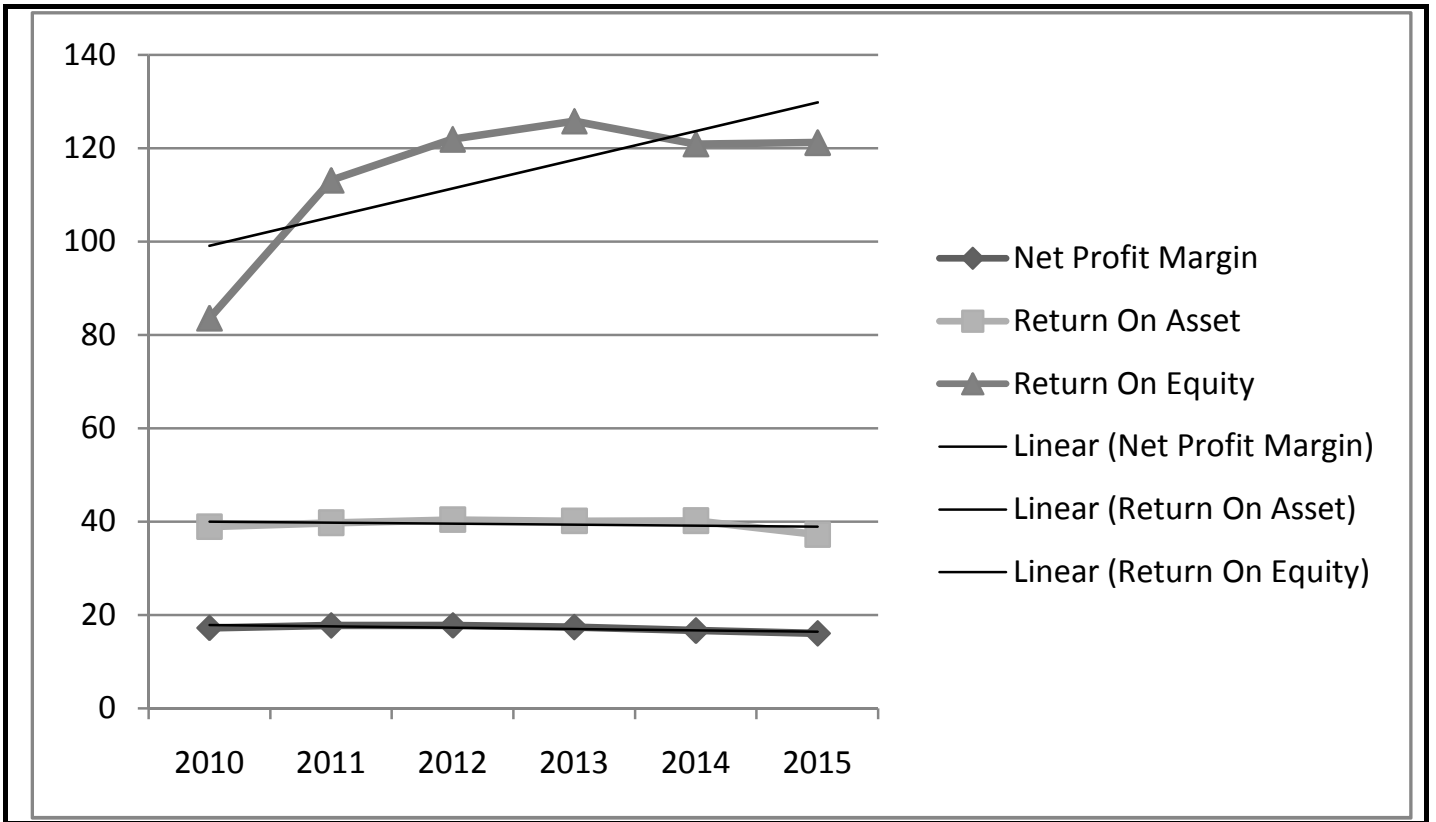

Sumber: Data diolah dari laporan keuangan PT. Unilever Indonesia, Tbk

Gambar 1. Trend Profitabilitas PT Unilever Indonesia, Tbk Periode 2010-2015

Nilai rasio profitabilitas PT. Unilever Indonesia Tbk yang diwakili oleh Net Profit Margin, Return On Equity, Return On Asset yang ditunjukkan oleh tabel diatas. Berdasarkan hasil perhitungan diatas dapat diketahui bahwa Net Profit Margin pada tahun 2010 sebesar 17,18\%. Pada tahun 2011 terjadi peningkatan 0,56\% menjadi 17,74\% . Pada tahun 2012 terjadi penurunan 0,02\% menjadi 17,72\% kemudian pada tahun 2013 kembali terjadi penurunan sebesar 0,32\% menjadi 17,40\%, pada tahun 2014 kembali terjadi penurunan sebesar 0,78\% menjadi 16,62\% dan yang terakhir pada tahun 2015 Net Profit Margin juga turun sebesar 0,59\% menjadi 16,03\%, sepanjang tahun penelitian Net Profit Margin PT Unilever Indonesia Tbk cenderung mengalami penurunan setiap tahunnya. Net Profit Margin tertinggi perusahaan diperoleh ditahun 2011. Menurunnya Net Profit Margin dari tahun ke tahun menunjukkan kinerja perusahaan yang kurang baik karena laba bersih dari setiap penjualan yang diperoleh dari tahun ketahun semakin menurun.

Berdasarkan gambar 1 diatas dapat dilihat bahwa Return on Equity (ROE) PT Unilever Indonesia Tbk sepanjang tahun 2010 sampai 2015 berturut-turut nilainya adalah $38,89 \%, 39,72 \%, 40,37 \%, 40,10 \%, 40,18 \%$ dan 37,20\% dengan nilai rata-rata $39,41 \%$. Nilai ROE selama tahun penelitian cenderung mengalami peningkatan. Nilai terendah ROE diperoleh pada tahun 2015 pada tahun tersebut perusahaan memperoleh laba terendah. Nilai ROE meningkat disebabkan adanya 
efisiensi kinerja dari PT Unilever Indonesia Tbk dalam mengoptimalkan modal sendiri untuk menghasilkan laba bersih.

Return on Asset (ROA) pada PT Unilever Indonesia Tbk selama tahun 2010 sampai tahun 2015 secara berturut-turut 83,59\%, 113,13\%, 121,94\%, $125,80 \%, 120,89 \%$ dan $121,22 \%$. Dapat dilihat bahwa nilai laba bersih perusahaan selama penelitian cenderung mengalami peningkatan dan mengakibatkan nilai ROA perusahaan juga meningkat. Naiknya nilai ROA dari tahun ke tahun menunjukkan bahwa kemampuan perusahaan untuk menghasilkan laba bersih yang maksimal dengan menggunakan aktivanya secara produktif semakin meningkat dengan demikian keuntungan yang diperoleh perusahaan berdasarkan investasi yang ditanamkan pada perusahaaan tersebut dalam kondisi rentabilitas ekonomis yang cukup baik.

Tujuan yang ingin dicapai dalam penulisan penelitian adalah untuk mengetahui bagaimana kinerja keuangan bila diukur dengan menggunakan rasio keuangan pada PT Unilever Indonesia Tbk.

\section{Rasio Keuangan}

Rasio keuangan menurut Horne dan John adalah indeks yang menghubungkan dua angka akuntansi dan dapat dengan membagi satu angka dengan yang lainnya. ${ }^{9}$ Alat yang sering kali digunakan selama pemeriksaan ini adalah rasio keuangan, atau indeks yang menghubungkan dua buah data keuangan dengan membagi satu angka dengan angka yang lainnya.

Dalam melaksanakan tugas dan tanggung jawabnya, manajemen akan melakukan berbagai aktivitas berkaitan dengan: evaluasi terhadap kinerja perusahaan, merencanakan aktivitas perusahaan dimasa yang akan datang serta mendapat gambaran apakah tujuan perusahaan sudah dapat dicapai. ${ }^{10}$

\section{Jenis-jenis Ratio Keuangan}

Menurut Brigham dan Joel secara umum rasio keuangan dibagi menjadi lima jenis. Dalam penelitian ini, penulis hanya menggunakan empat jenis rasio yaitu:

\section{Rasio Likuiditas (Liquidity Ratio)}

Rasio likuiditas merupakan rasio yang digunakan untuk mengukur kemampuan perusahaan untuk memenuhi kewajiban jangka pendek dan membandingkan kewajiban jangka pendek dengan sumber daya jangka pendek 
(atau lancar) yang tersedia untuk memenuhi kewajiban tersebut. Rasio likuiditas terdiri dari:

a) Ratio Lancar (Current ratio)

Current Ratio adalah rasio yang menunjukkan kemampuan perusahaan untuk membayar kewajiban jangka pendeknya dengan menggunakan aktiva lancarnya. Semakin tinggi rasio lancar, maka akan semakin besar kemampuan perusahaan untuk membayar berbagai tagihannya.

$$
\text { Rasio lancar }=\frac{\text { Aset lancar }}{\text { Kewajiban Lancar }}
$$

b) Ratio cepat (Quick Ratio)

Rasio yang menunjukkan kemampuan perusahaan memenuhi, membayar kewajiban atau utang lancar (utang jangka pendek) dengan aktiva lancar tanpa memperhitungkan nilai persediaan. Rasio cepat digunakan untuk mengukur kemampuan suatu perusahaan untuk membayar kewajiban jangka pendek tanpa mengadalkan penjualan persediaan yang sangat penting artinya, persediaan pada umumnya merupakan aset lancar perusahaan yang paling tidak likuid sehingga perusahaan merupakan aset, dimana kemungkinan besar akan terjadi kerugian jika terjadi likuidasi. Rumus untuk menghitung rasio cepat adalah:

$$
\text { Rasio Cepat }=\frac{\text { Aset lancar }- \text { Persediaaan }}{\text { Kewajiban Lancar }}
$$

\section{Rasio Manajemen Aset}

Rasio manajemen aset untuk mengukur efektivitas perusahaan dalam pengelolaan aktivanya, yaitu mengukur kemampuan seluruh aktivanya dalam menghasilkan penjualan. Rasio ini terdiri dari:

a) Rasio Perputaran Persediaan

Sesuai dengan namanya, rasio ini menunjukkan berapa kali pos tersebut “berputar" sepanjang tahun. Rasio ini dapat dihitung dengan rumus :

$$
\text { Rasio Perputaran Persediaan }=\frac{\text { Penjualan }}{\text { Persediaan }}
$$

b) Rasio Perputaran Aset Tetap

Rasio perputaran aset tetap digunakan untuk mengukur seberapa efektif perusahaan menggunakan pabrik dan peralatannya. Rumusnya adalah:

$$
\text { Rasio Perputaran Aset Tetap }=\frac{\text { Penjualan }}{\text { Aset Tetap Bersih }}
$$


c) Rasio Perputaran Total Aset

Ratio ini digunakan untuk mengukur perputaran seluruh aset perusahaan. Rumus untuk menghitung perputaran total aset adalah:

$$
\text { Rasio Perputaran Total Aset }=\frac{\text { Penjualan }}{\text { Total Aset }}
$$

\section{Rasio Manajemen Utang (Leverage)}

Laverage ratio adalah rasio yang menunjukkan sejauh mana perusahaan dibayar oleh utang. Rasio ini menunjukkan proporsi atas penggunaan utang untuk membiayai investasinya, perusahaan yang tidak mempunyai laverage berarti menggunakan modal sendiri $100 \%$.

a) Debt to Total Asset Ratio (DAR)

Rasio ini digunakan untuk menghitung rasio total utang terhadap total aset. Total utang termasuk seluruh kewajiban lancar dan utang jangka panjang semakin tinggi Debt to Total Asset Ratio (DAR) semakin besar risiko keuangannya, semakin rendah rasio ini maka semakin rendah risiko keuangannya. Rumusnya adalah:

$$
D \quad \text { i } T \quad A \quad R=\frac{\text { Total Hutang }}{\text { Total Aset }}
$$

b) Debt to Total Equity Ratio (DER)

Rasio ini digunakan untuk menghitung rasio utang terhadap total ekuitas. Total utang termasuk seluruh kewajiban lancar dan utang jangka panjang. Rumusnya:

$$
D \quad \text { ti } T \quad E \quad R \quad=\frac{\text { Total Hutang }}{\text { Total Ekuitas }}
$$

c) Rasio Kelipatan Pembayaran Bunga (Time Interest Earned - TIE)

Rasio kelipatan pembayaran bunga mengukur sampai sejauh apa laba operasi dapt mengalami penurunan sebelum perusahaan tidak mampu memenuhi biaya bunga tahunannya. Kegagalan dalam membayar bunga akan menyebabkan pihak kreditor melakukan tindakan hukum dan kemungkinan berakhir dengan kebangkrutan. Dalam perhitungan rasio ini dibutuhkan rasio laba sebelum bunga dan pajak (Earnings Before Interest and Taxes atau EBIT). Rumusnya adalah:

$$
\mathrm{Ti} \quad \mathrm{I1} \quad \mathrm{E} \quad=\frac{\mathrm{EBIT}}{\text { Beban Bunga }}
$$




\section{Rasio Profitabilitas}

Rasio Profitabilitas adalah sekelompok rasio yang menunjukkan gabungan efek-efek dari lukuiditas, manajemen aktiva, dan utang pada hasil-hasil operasi, rasio ini terdiri dari:

a) Margin laba atas Penjualan (Net Profit Margin)

Rasio ini menunjukkan seberapa banyak keuntungan operasional bisa diperoleh dari setiap mata uang (bisa IDR atau US S) penjualan. Dengan menggunakan rasio ini kita dapat melihat bagaimana marjin laba dan penggunaan hutang berinteraksi untuk mempengaruhi pengembalian pemegang saham dalam waktu dekat. Rumus untuk menghitung marjin laba atas penjualan, yaitu:

$$
\text { Prit } \quad \text { Margin On Sales }=\frac{\text { Laba Bersih setelah Pajak }}{\text { Penjualan }}
$$

b) Return on Asset (ROA)

Rasio ini menunjukkan kemampuan aktiva perusahaan memperoleh laba dari operasi perusahaan. Aset yang digunakan dalam mengukur kemampuan memperoleh laba adalah aset operasional. Rumusnya adalah:

$$
R \quad O A \quad(\mathrm{ROA})=\frac{\text { Laba Bersih setelah Pajak }}{\text { Total Asset }}
$$

c) Return on Equity (ROE)

Rasio laba bersih terhadap Ekuitas saham biasa umumnya mengukur pengembalian atas ekuitas saham biasa (Return On Equity atau ROE) atau tingkat pengembalian atas investasi pemegang saham. Dengan kata lain, rasio ini menunjukkan seberapa besar keuntungan yang menjadi hak pemilik modal sendiri. Rumusnya adalah: ${ }^{11}$

$$
\begin{array}{llll}
r & O & E & (\mathrm{ROE})
\end{array}=\frac{\text { Laba Bersih setelah Pajak }}{\text { Modal sendiri }}
$$

\section{Metode Penelitian}

Jenis data yang diperlukan dalam penelitian ini adalah data yang bersifat kualitatif dan data kuantitatif. Data kualitatif yang digunakan yaitu struktur organisasi dan gambaran umum perusahaan PT Unilever, Tbk yang diakses melalui website: http://www.unilevertbk.com. ${ }^{12}$ Sedangkan data kuantitatif yang berbentuk angka atau data yang diangkakan. sebagai data kuantitatif dalam penelitian ini adalah laporan keuangan periode 2011 sampai dengan 2015 dari PT. Unilever, Tbk yang terdaftar di Bursa Efek Indonesia diakses melalui website : 
http://www.idx.co.id. ${ }^{13}$ Sumber data yang digunakan dalam penelitian ini adalah data sekunder, yaitu laporan keuangan yang diperoleh dan dipublikasikan oleh Bursa Efek Indonesia dari situs resminya di website http://www.idx.co.id dan http://www.unilevertbk.com.

Adapun kerangka berfikir sebagai berikut:

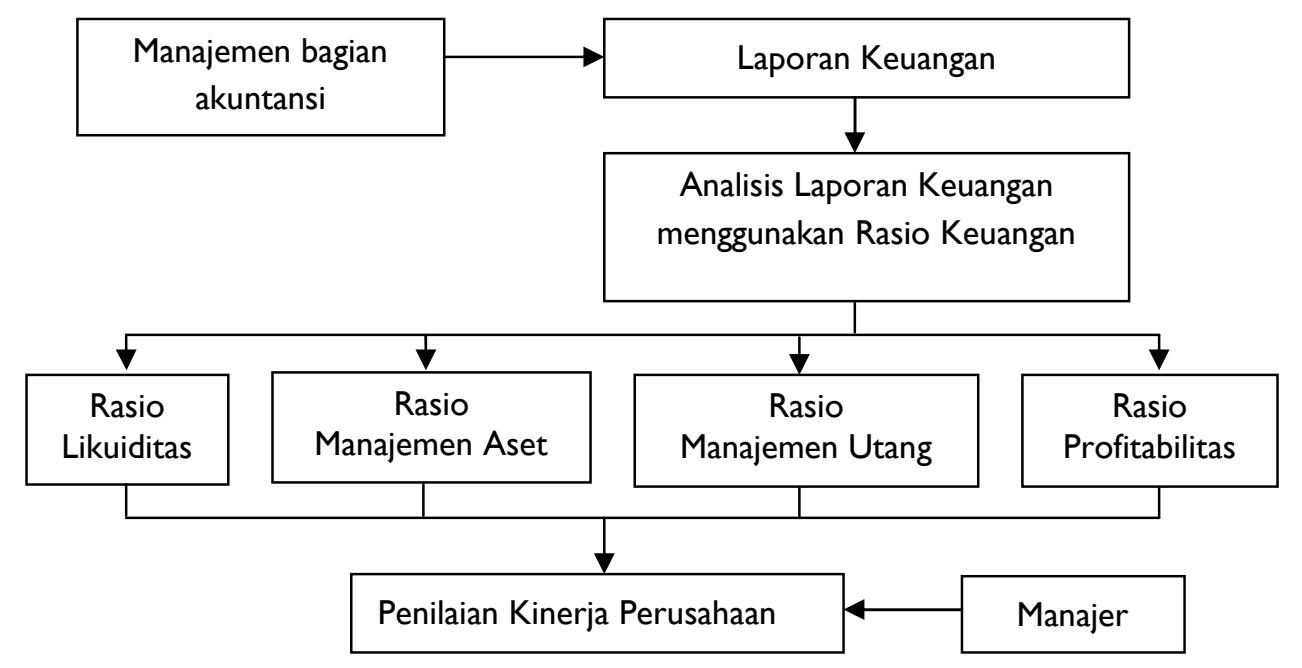

Gambar 2. Kerangka Berfikir Penilaian kinerja Perusahaan

\section{Hasil Penelitian}

Berikut ini analisis laporan keuangan PT Unilever Tbk yang terdaftar dibursa efek Indonesia mulai tahun 2010 sampai dengan 2015.

\section{Analisis Rasio Likuiditas (Likuidity Ratio)}

Rasio likuiditas adalah asset yang diperdagangkan di pasar aktif sehingga dapat dikonversi dengan cepat menjadi kas pada harga pasar yang berlaku.

Tabel 2. Current Ratio dan Quick Ratio PT Unilever Tbk

\begin{tabular}{|c|c|c|c|}
\hline No & Tahun & $\begin{array}{c}\text { Current Ratio } \\
(\%)\end{array}$ & $\begin{array}{c}\text { Quick Ratio } \\
(\%)\end{array}$ \\
\hline 1 & 2010 & 85,12 & 49,37 \\
\hline 2 & 2011 & 68,67 & 40,50 \\
\hline 3 & 2012 & 66,82 & 39,46 \\
\hline 4 & 2013 & 69,63 & 44,87 \\
\hline 5 & 2014 & 71,49 & 45,25 \\
\hline 6 & 2015 & 65,39 & 42,71 \\
\hline
\end{tabular}

Sumber: Data diolah dari laporan keuangan PT Unilever Tbk 
Berdasarkan tabel 2 diatas dapat diketahui nilai Current Ratio PT Unilever Tbk dari tahun 2010 sampai tahun 2015 mengalami penurunan yaitu 85,12\%, $68,67 \%, 66,82 \%, 69,63 \%, 71,49 \%$ dan 65,39\%. Nilai ratio ini berarti setiap Rp. 100 utang lancar dijamin dengan aktiva lancar sebesar: Rp. 85,12 ditahun 2010, Rp. 68,67 ditahun 2011, Rp. 66,82 ditahun 2012, Rp.69,63 ditahun 2013, Rp.71,49 ditahun 2014 dan Rp. 65,39 ditahun 2015. Dari tabel diatas juga diketahui bahwa Current Ratio PT Unilever Tbk cenderung mengalami penurunan yang menandakan keadaan likuiditas perusahaan kurang baik. Dari hasil perhitungan Current Ratio diatas dapat diketahui bahwa rasio likuiditas terjadi penurunan. Perusahaan dinyatakan likuid karena aktiva lancar perusahaan cukup untuk memenuhi kewajiban jangka pendeknya terlihat dari trend-nya yang menurun. Nilai rasio ini cukup rendah dan menunjukkan keadaan perusahaan kurang likuid yaitu asset lancar yang dimiliki perusahaan tidak mampu untuk membayar kewajiban lancar perusahaan. Peningkatan nilai kewajiban lancar selama tahun penelitian ini tidak dibarengi dengan peningkatan nilai asset lancar perusahaan. Jadi dapat dikatakan bahwa kinerja keuangan sedikit menurun karena kemampuan aset lancar yang dimiliki perusahaan tidak memenuhi kewajiban lancarnya. Dalam penelitian ini bertolak belakang dengan penelitian yang pernah dilakukan oleh Anang Candra Wahyudi dimana hasil penelitian nya pada PT Unilever Tbk periode 2006-2007 nilai Current Ratio menunjukkan sedikit mengalami penurunan, walaupun demikian kinerja keuangan dikatakan sudah cukup baik apabila diukur dari tingkat rasio $100 \%$ karena perusahaan dapat dikatakan baik jika mempunyai nilai Current Ratio lebih besar dari $100 \%$. $^{14}$

Nilai Quick Ratio PT Unilever Tbk yang terdaftar di bursa efek Indonesia dari tahun 2010 sampai dengan 2015 stabil yaitu 49,37\%, 40,50\%, 39,46\%, 44,87\%, 45,25\% dan 42,71\%. Nilai rasio ini berarti Quick Ratio pada tahun 2010 yaitu setiap Rp. 100 kewajiban dijamin dengan Rp. 49,37 aset lancar yang cepat diuangkan. Quick Ratio pada tahun 2011 yaitu setiap Rp. 100 kewajiban dijamin dengan Rp. 40,50 aset lancar yang cepat diuangkan. Quick Ratio pada tahun 2012 yaitu setiap Rp. 100 kewajiban dijamin dengan Rp. 39,46 aset lancar yang cepat diuangkan. Quick Ratio pada tahun 2013 yaitu setiap Rp. 100 kewajiban dijamin dengan Rp. 44,87 aset lancar yang cepat diuangkan. Quick Ratio pada tahun 2014 yaitu setiap Rp. 100 kewajiban dijamin dengan Rp. 45,25 aset lancar yang cepat diuangkan. Quick Ratio pada tahun 2015 yaitu setiap Rp.100 kewajiban dijamin 
dengan Rp. 42,71 aset lancar yang cepat diuangkan. Berdasarkan perhitungan Quick Ratio diatas terjadi penurunan. Hal ini menunjukkan bahwa jumlah kewajiban lancar yang terus meningkat lebih tinggi dari pada aset lancar dan persediaan. Dengan demikian, kondisi perusahaan yang likuid dan kinerja yang dimiliki menurun dari tahun ke tahun. Untuk meningkatkan tingkat likuiditasnya, perusahaan perlu meningkatkan penggunaan dananya sehingga aktiva lancar akan semakin tinggi. Kenaikan aktiva lancar dapat dilakukan antara lain dengan menjual aktiva tetap, mendapatkan tambahan modal sendiri dan mendapatkan tambahan hutang jangka panjang. Jadi, dapat disimpulkan bahwa Perusahaan Unilever dalam memenuhi kewajiban lancarnya belum dapat dikatakan baik dari perhitungan Quick Ratio nya. Penelitian ini sama seperti penelitian yang dilakukan oleh Anne Erika Oktania dan Soedjono dimana hasil penelitian nya menunjukkan bahwa kinerja keuangan PT Telekomunikasi Indonesia Tbk dari tahun 2007-2011 dilihat dari likuiditas dikatakan kurang baik dalam hal ini Quick Ratio karena likuiditas perusahaan masih dibawah data time series sebagai tolak ukur. $^{15}$

\section{Analisis Rasio Manajemen Aset}

Hasil rasio manajemen aset terhadap laporan keuangan yang dimiliki PT Unilever Tbk seperti yang ada pada tabel 3 berikut ini.

Tabel 3. Rasio Manajemen Aset PT Unilever Tbk

\begin{tabular}{|c|c|c|c|c|}
\hline No & Tahun & $\begin{array}{c}\text { Perputaran } \\
\text { Persediaan }\end{array}$ & $\begin{array}{c}\text { Perputaran Aset } \\
\text { Tetap }\end{array}$ & $\begin{array}{c}\text { Perputaran Total } \\
\text { Aset }\end{array}$ \\
\hline 1 & 2010 & 12,50 & 3,97 & 2,26 \\
\hline 2 & 2011 & 12,94 & 3,88 & 2,23 \\
\hline 3 & 2012 & 13,24 & 3,92 & 2,27 \\
\hline 4 & 2013 & 14,75 & 4,34 & 2,30 \\
\hline 5 & 2014 & 14,83 & 4,10 & 2,41 \\
\hline 6 & 2015 & 15,87 & 4,00 & 2,31 \\
\hline \multicolumn{2}{|c|}{ Rata-rata } & $\mathbf{1 4 , 0 2}$ & $\mathbf{1 4 , 0 4}$ & $\mathbf{2 , 3 0}$ \\
\hline
\end{tabular}

Sumber: Data diolah dari laporan keuangan PT Unilever Tbk

Dari hasil perhitungan pada tabel 3 menunjukkan nilai rasio manajemen aset PT Unilever Tbk, diantaranya rasio perputaran persediaan, rasio perputaran aset tetap dan rasio perputaran total aset. Untuk rasio perputaran persediaan selama tahun penelitian yaitu pada tahun 2010 sampai tahun 2015 mengalami peningkatan. Pada tahun 2010 perputaran persediaaan sebesar 12,50 dan pada 
tahun 2011 perputaran persediaan sebesar 12,94 ini berarti terjadi kenaikan sebesar 0,44\%. Pada tahun 2011 hingga tahun 2012 terjadi kenaikan perputaran persediaaan sebesar 0,30\% menjadi 13,24. Pada tahun 2012 hingga tahun 2013 terjadi kenaikan perputaran persediaaan sebesar 1,51\% menjadi 14,75. Pada tahun 2013 hingga tahun 2014 terjadi kenaikan perputaran persediaaan sebesar 0,08\% menjadi 14,83. Pada tahun 2014 hingga tahun 2015 perputaran persediaaan kembali mengalami kenaikan yaitu sebesar $1,04 \%$ menjadi 15,87 . Nilai rasio perputaran persediaan PT Unilever Tbk berturut-turut dari tahun 2010 sampai tahun 2015 adalah 12,50 kali, 12,94 kali, 13,24 kali, 14,75 kali, 14,83 kali, 15,87 kali. Nilai rasio perputaran persediaan tahun 2010 sampai tahun 2015 mengalami peningkatan, hal ini menunjukkan efisiensi manajemen perusahaan dalam menggunakan aset perusahaan untuk menghasilkan peningkatan pendapatan sepanjang tahun yang diteliti. Perusahaan ini dinilai sudah efektif dalam mengelola persediaannya. Apabila perputaran persediaan ini semakin besar maka semakin baik pula kondisi suatu perusahaan, berarti kegiatan penjualan berjalan cepat. Ini artinya kinerja keuangan PT Unilever Tbk dikategorikan baik, hal ini ditunjukkan dengan masa perputaran persediaan dari tahun ke tahun yang mengalami peningkatan, sehingga akan mempercepat persediaan tersebut menjadi uang kembali. Penelitian Yuli Orniati pada PT Wira Jatim Group Pabrik Es Betek Malang menyatakan bahwa perputaran persediaan mulai tahun 2005-2007 menunjukkan jumlah yang berfluktuasi meskipun dalam jumlah yang kecil, menurunnya jumlah perputaran persediaan maka berdampak pada jumlah persediaan baik persediaan bahan baku, barang setengah jadi dan barang jadi, berakibat pada menurunnya volume penjualan sehingga secara langsung akan menurunkan jumlah laba yang akan diperoleh perusahaan. ${ }^{16}$

Berdasarkan perhitungan diatas untuk nilai rasio perputaran aset tetap selama tahun penelitian yaitu tahun 2010 sampai tahun 2015 terjadi penurunan dan kenaikan. Pada tahun 2010 perputaran aset tetap adalah sebesar 3,97 dan pada tahun 2011 perputaran aset tetap sebesar 3,88 berarti terjadi penurunan sebesar 0,09\%. Sedangkan pada tahun 2012 perputaran aset tetap mengalami kenaikan sebesar 0,04\% menjadi 3,92. Pada tahun 2013 perputaran aset tetap kembali mengalami kenaikan sebesar 0,42\% menjadi 4,34. Pada tahun 2014 perputaran aset tetap mengalami penurunan menjadi 4,10 atau turun sebesar 0,24\%. Kemudian pada tahun 2015 perputaran aset tetap kembali mengalami penurunan 
menjadi 4,00 atau turun sebesar 0,10\% dari tahun sebelumnya. PT Unilever Tbk berturut-turut dari tahun 2010 sampai tahun 2015 adalah 3,97 kali, 3,88 kali,3,92 kali, 4,34 kali, 4,10 kali dan 4,00 kali. Berdasarkan hasil analisis setelah 2 tahun awal penelitian mengalami penurunan, namun ditahun ke 3 tapatnya tahun 2012 dan 2013 mengalami peningkatan dan pada 2 tahun terakhir tepatnya pada tahun 2014 dan 2015 rasio perputaran aset tetap mengalami penurunan kembali. Hal ini disebabkan oleh peningkatan nilai penjualan masih lebih rendah dibanding total modal perusahaan. Penurunan ini menunjukkan modal kerja perusahaan untuk menghasilkan pendapatan mengalami penurunan. Penelitian ini sama seperti penelitian yang dilakukan oleh Riswan dan Yolanda Fatrecia Kesuma dimana hasil penelitiannya pada PT Budi Satria Wahana Motor menunjukkan bahwa kemampuan perusahaan didalam mengelola aktiva tetapnya terhadap pencapaian penjualan menurun. ${ }^{17}$ Sedangkan penelitian Recly Bima Rhamadana dan Triyonowati pada PT H. M Sampoerna Tbk selama tahun 2010-2014 dikatakan baik karena di atas rata-rata angka standart yang menunjukkan bahwa perusahaan cukup efektif dalam pengelolaan aktiva perusahaan. ${ }^{18}$

Pada perhitungan perputaran total aset dari tahun 2010 hingga tahun 2015 mengalami penurunan dan kenaikan. Pada tahun 2010 perputaran total aset adalah sebesar 2,26 dan pada tahun 2011 perputaran total aset sebesar 2,23 berarti terjadi penurunan sebesar $0,03 \%$. Sedangkan pada tahun 2012 perputaran total aset mengalami kenaikan sebesar 0,04\% menjadi 2,27. Pada tahun 2013 perputaran total aset mengalami kenaikan sebesar 0,03\% menjadi 2,30. Pada tahun 2014 perputaran total aset mengalami kenaikan sebesar 0,11\% menjadi 2,41. Kemudian pada tahun 2015 perputaran total aset kembali mengalami penurunan menjadi 2,31 atau turun sebesar $0,10 \%$ dari tahun sebelumnya. Nilai rasio perputaran total aset PT Unilever Tbk berturut-turut dari tahun 2010 sampai tahun 2015 adalah 2,26 kali, 2,23 kali, 2,27 kali, 2,30 kali, 2,41 kali dan 2,31 kali. Berdasarkan hasil analisis, setelah 2 tahun awal penelitian mengalami penurunan namun ditahun ke 3 tapatnya tahun 2012 sampai tahun 2014 mengalami peningkatan dan pada tahun terakhir tepatnya pada tahun 2015 rasio perputaran total aset mengalami penurunan kembali. Apabila rasio perputaran total aset ini semakin rendah maka semakin buruk pula kemampuan semua aktiva menciptakan penjualannya. Ini artinya kinerja keuangan PT Unilever Tbk dapat dikatakan cukup baik, hal ini 
disebabkan karena dana yang tertanam pada keseluruhan aktiva perputarannya mengalami kenaikan. Dalam penelitian lain yang dilakukan oleh Moch Ainul Yaqin dan Sri Utiyati dimana dari ketiga perusahaan semen yang terdaftar di Bursa Efek Indonesia yaitu PT Semen Gresik (Persero), PT Indocement Tunggal Prakasa Tbk dan PT Holcim Indonesia Tbk dilihat dari tingkat total aset perusahaan selama tahun 2007-2013. PT Semen Gresik (Persero) Tbk memiliki kemampuan dalam mengelola seluruh aktivanya lebih baik dibandingkan PT Indocement Tunggal Prakasa Tbk dan PT Holcim Indonesia Tbk yang memiliki tingkat rata-rata total aset lebih rendah. ${ }^{19}$

\section{Analisis Rasio Manajemen Utang}

Analisis laporan keuangan yang dimiliki PT Unilever Tbk untuk rasio manajemen utang, hasil ditunjukkan oleh tabel di bawah ini:

Tabel 4 Rasio Manajemen Utang PT Unilever Tbk

\begin{tabular}{|c|c|c|c|c|}
\hline No & Tahun & $\begin{array}{c}\text { Debt toTotal } \\
\text { Asset Ratio } \\
\text { (DAR) \% }\end{array}$ & $\begin{array}{c}\text { Debt toTotal } \\
\text { Equity Ratio } \\
\text { (DER) \% }\end{array}$ & $\begin{array}{c}\text { Time Interest } \\
\text { Earned } \text {-TIE } \\
\text { (kali) }\end{array}$ \\
\hline 1 & 2010 & 53,46 & 114,90 & 199,34 \\
\hline 2 & 2011 & 64,88 & 184,77 & 210,36 \\
\hline 3 & 2012 & 66,88 & 202,01 & 93,87 \\
\hline 4 & 2013 & 68,12 & 213,73 & 355,83 \\
\hline 5 & 2014 & 66,76 & 200,86 & 82,52 \\
\hline 6 & 2015 & 69,31 & 225,84 & 64,96 \\
\hline \multicolumn{2}{|c|}{ Rata-rata } & $\mathbf{6 4 , 9 0 1 6}$ & $\mathbf{1 9 0 , 3 5 1 6}$ & $\mathbf{1 6 7 , 8 1 3 3}$ \\
\hline
\end{tabular}

Sumber: Data diolah dari laporan keuangan PT Unilever Tbk

Dari tabel 4 dapat diketahui bahwa PT Unilever Tbk sepanjang tahun 2010 sampai 2015 pada analisis rasio total utang terhadap total aktiva di tahun 2010 hasil analisis debt to total asset ratio (DAR) sebesar 53,46\% berarti bahwa setiap rupiah aktiva digunakan untuk menjamin hutang sebesar Rp. 53,46. Pada tahun 2011 debt to total asset ratio sebesar 64,88\% mengalami peningkatan sebesar $11,4 \%$ dari yang semula $53,46 \%$ menjadi $64,88 \%$ ini berarti bahwa setiap rupiah aktiva digunakan untuk menjamin hutang sebesar Rp. 64,88. Pada tahun 2012 mengalami peningkatan sebesar $2 \%$ dari yang semula $64,88 \%$ menjadi $66,88 \%$, ini menunjukkan bahwa setiap rupiah aktiva akan digunakan untuk menjamin hutang sebesar Rp. 66,88. Pada tahun 2013 kembali mengalami peningkatan sebesar $1,26 \%$ dari yang semula $66,88 \%$ menjadi $68,12 \%$, ini menunjukkan 
bahwa setiap rupiah aktiva akan digunakan untuk menjamin hutang sebesar Rp.68,12. Pada tahun 2014 debt to total asset ratio sebesar 66,76\%, mengalami penurunan sebesar $1,36 \%$ dari yang semula $68,12 \%$ menjadi $66,76 \%$ ini berarti bahwa setiap rupiah aktiva digunakan untuk menjamin hutang sebesar Rp. 66,76. Pada tahun 2015 debt to total asset ratio sebesar 69,71\%, mengalami peningkatan sebesar 2,95\% dari yang semula 66,76\% menjadi 69,71\%, ini menunjukkan bahwa setiap rupiah aktiva akan digunakan untuk menjamin hutang sebesar Rp. 69,71. Jadi dapat ditarik kesimpulan bahwa total hutang terhadap total aktiva dari tahun 2010 sampai dengan tahun 2015 sudah cukup baik karena hanya sekali mengalami penurunan yaitu pada tahun 2013 hingga tahun 2014 saja. Kenaikan rasio ini disebabkan perusahaan mengalami kenaikan total hutang lebih besar dibanding dengan kenaikan total aset. Hal ini menunjukkan kemampuan perusahaan untuk bertahan dalam periode waktu yang cukup panjang kurang baik. Semakin besar debt to total asset ratio akan menunjukkan semakin besar pula porsi penggunaan hutang dalam membiayai investasi aktivanya, yang berarti resiko keuangan perusahaan meningkat yang disebabkan ketidakmampuan perusahaan dalam membayar kewajibannya. debt to total asset ratio yang tinggi dapat pula menyebabkan resiko kebangkrutan perusahaan semakin besar. Berbeda dengan penelitian yang dilakukan oleh Anita Aprilia dan Lailatul Amanah dimana hasil penelitian nya menunjukkan bahwa perhitungan rasio total hutang terhadap total aset pada Koperasi Dhaya Harta Jombang untuk tahun 2007-2011 bahwa rasio mengalami penurunan dari tahun ke tahun, hal tersebut menggambarkan Koperasi yang baik dikarenakan semakin kecil nilai rasio akan semakin sehat Koperasi tersebut. ${ }^{20}$

Dari hasil perhitungan diatas menunjukkan bahwa Debt to Equity Ratio mengalami kenaikan. Ditahun 2010 nilai Debt to Equity Ratio menunjukan nilai $114,90 \%$. Artinya, bahwa 114,90\% modal perusahaan dibiayai dengan hutang. Ditahun 2011 nilai Debt to Equity Ratio adalah sebesar 184,77\%, mengalami kenaikan sebesar 69,87\% dari tahun sebelumnya, hal ini berarti 184,77\% modal perusahaan dibiayai dengan hutang. Pada tahun 2012 Debt to Equity Ratio $202,01 \%$ mengalami kenaikan sebesar $17,24 \%$ dari tahun sebelumnya, hal ini berarti 202,01\% modal perusahaan dibiayai dengan hutang. Pada tahun 2013 Debt to Equity Ratio $213,73 \%$ mengalami kenaikan sebesar $11,72 \%$ dari tahun 
sebelumnya, hal ini berarti $213,73 \%$ modal perusahaan dibiayai dengan hutang. Kemudian pada tahun 2014 terjadi penurunan Debt to Equity Ratio sebesar $12,87 \%$ dari $213,73 \%$ menjadi $200,86 \%$ ini berarti bahwa $200,86 \%$ modal perusahaan dibiayai dengan hutang. Pada tahun 2015 Debt to Equity Ratio kembali terjadi kenaikan menjadi $225,84 \%$ atau mengalami kenaikan sebesar $24,98 \%$ dari tahun sebelumnya, hal ini berarti $225,84 \%$ modal perusahaan dibiayai dengan hutang. Jadi dapat disimpulkan bahwa kinerja keuangan PT Unilever Tbk yang diukur dari Debt to Equity Ratio dikatakan belum baik karena Semakin tinggi DER menunjukkan komposisi total hutang (jangka pendek dan jangka panjang) semakin besar dibanding dengan total modal sendiri, sehingga berdampak semakin besar beban perusahaan terhadap pihak luar (kreditur) maka diasumsikan perusahaan memiliki resiko yang semakin tinggi terhadap likuiditas perusahaannya. Sebaliknya semakin rendah DER akan semakin baik kemampuan perusahaan dalam membayar kewajiban jangka panjangnya. Penelitian Ceicilia Sri Haryanti menyatakan bahwa Debt to Equity Ratio pada PT Telekomunikasi Indonesia Tbk periode 2010-2014 menunjukkan selalu terjadi penurunan persentase ditiap tahunnya. Hal ini dinilai baik karena semakin kecil rasio ini menunjukan semakin kecil pula persentase hutang dalam membiayai modal perusahaan, ${ }^{21}$ begitu juga dengan penelitian yang dilakukan Anita Aprilia dan Lailatul Amanah dimana Rasio mengalami penurunan dari tahun ke tahun, hal tersebut menggambarkan Koperasi yang baik dikarenakan semakin kecil nilai rasio akan semakin sehat Koperasi tersebut. Berdasarkan standar Peraturan Menteri KUKM Indonesia rasio ini tergolong dalam kondisi yang sehat. $^{22}$

Times Interest Earned tahun 2010 adalah 199,34 kali atau dengan kata lain, biaya bunga dapat ditutup 199,34 kali dari laba sebelum bunga dan pajak. Lalu tahun 2011 adalah 210,36 kali atau dengan kata lain biaya bunga dapat ditutup 7,6 kali dari laba sebelum bunga dan pajak. Tahun 2012 adalah 93,87 kali atau dengan kata lain, biaya bunga dapat ditutup 93,87 kali dari laba sebelum bunga dan pajak. Tahun 2013 adalah 355,83 kali atau dengan kata lain biaya bunga dapat ditutup 355,83 kali dari laba sebelum bunga dan pajak. Tahun 2014 adalah 82,52 kali atau dengan kata lain, biaya bunga dapat ditutup 82,52 kali dari laba sebelum bunga dan pajak. Tahun 2015 adalah 64,96 kali atau dengan kata lain biaya bunga dapat ditutup 64,96 kali dari laba sebelum bunga dan pajak. 
Times Interest Earned dapat digunakan untuk melihat kemampuan perusahaan membayar bunga dan utang. Jika menggunakan perbandingan lebih dari satu periode, maka nilai times interest earned yang semakin besar akan semakin bagus, dalam arti, EBIT yang dimiliki perusahaan lebih besar nilainya dari pada beban bunga yang harus dibayar, sehingga dalam hal ini PT Unilever Tbk telah mampu menutupi beban bunga dengan EBIT yang dimilikinya. Pada penelitian Yuli Orniati di PT. Wira Jatim Group Pabrik Es Betek Malang periode 2005-2007 yang mana tingkat prosentase Time Interest Earned Ratio mengalami peningkatan, menunjukkan pada periode tersebut laba perusahaan mengalami peningkatan dalam menjamin beban bunga yang ditanggung, kondisi tersebut juga membuktikan bahwa selama periode tersebut terjadi peningkatan atas laba perusahaan, yang diakibatkan telah maksimalnya kemampuan perusahaan dalam menghasilkan penjualan bersih sehingga dapat menutup beban bunga yang ditanggung. $^{23}$

\section{Analisis Rasio Profitabilitas}

Analisis dari laporan keuangan yang dimiliki PT Unilever Tbk untuk rasio profitabilitas hasilnya akan ditunjukkan oleh table 5 berikut ini:

Tabel 5 Rasio Profitabilitas PT Unilever Tbk

\begin{tabular}{|c|c|c|c|c|}
\hline No & Tahun & $\begin{array}{c}\text { Profit Margin on } \\
\text { Sales (\%) }\end{array}$ & $\begin{array}{c}\text { Return on } \\
\text { Equity (\%) }\end{array}$ & $\begin{array}{c}\text { Return On } \\
\text { Asset (\%) }\end{array}$ \\
\hline 1 & 2010 & 17,18 & 38,89 & 83,59 \\
\hline 2 & 2011 & 17,74 & 39,72 & 113,13 \\
\hline 3 & 2012 & 17,72 & 40,37 & 121,94 \\
\hline 4 & 2013 & 17,40 & 40,10 & 125,80 \\
\hline 5 & 2014 & 16,62 & 40,18 & 120,89 \\
\hline 6 & 2015 & 16,03 & 37,20 & 121,22 \\
\hline \multicolumn{2}{|c|}{ Rata-rata } & $\mathbf{1 7 , 1 1 5}$ & $\mathbf{3 9 , 4 1}$ & $\mathbf{1 1 4 , 4 2 8 3 3}$ \\
\hline
\end{tabular}

Sumber: Data diolah dari laporan keuangan PT Unilever Tbk

Nilai rasio profitabilitas PT Unilever Tbk yang diwakili oleh Profit Margin on Sales, Return on Equity, Return on Asset yang ditunjukkan oleh tabel diatas. Berdasarkan hasil perhitungan diatas dapat diketahui bahwa profit margin pada tahun 2010 sebesar 17,18\%. Pada tahun 2011 terjadi peningkatan 0,56\% menjadi 17,74\%. Pada tahun 2012 terjadi penurunan 0,02\% menjadi 17,72\% kemudian pada tahun 2013 kembali terjadi penurunan sebesar 0,32\% menjadi 17,40\%, pada tahun 2014 kembali terjadi penurunan sebesar $0,78 \%$ menjadi 
16,62\% dan yang terkahir pada tahun 2015 profit margin juga turun sebesar 0,59\% menjadi 16,03\%, sepanjang tahun penelitian Profit Margin on Sales PT Unilever Tbk cenderung mengalami penurunan setiap tahunnya. Profit Margin on Sales tertinggi perusahaan diperoleh ditahun 2011. Menurunnya Profit Margin on Sales dari tahun ke tahun menunjukkan kinerja perusahaan yang kurang baik karena laba bersih dari setiap penjualan yang diperoleh perusahaan dari tahun ketahun semakin menurun. Berbeda dengan penelitian yang dilakukan oleh Ingrid Emilia Turang bahwa Net Profit Margin PT Bank BTPN selama 3 tahun mengalami kenaikan. Hal ini menunjukkan bahwa PT Bank BTPN Tbk dalam praktiknya memperoleh tingkat keuntungan yang diterimanya dari kegiatan operasional. ${ }^{24}$ Dalam penelitian yang dilakukan oleh Dedi Suhendro Analisis rasio profitabilitas pada PT Siantar Top Tbk menunjukkan kinerja perusahaan yang baik dan efisien apabila ditinjau nilai rata-rata rasio Net Profit Margin karena berada diatas rata-rata industri (time series). ${ }^{25}$

Return On Equity (ROE) PT Unilever Tbk sepanjang tahun 2010 sampai 2015 berturut-turut nilainya adalah 38,89\%, 39,72\%, 40,37\%, 40,10\%, 40,18\% dan $37,20 \%$ dengan nilai rata-rata $39,41 \%$. Nilai ROE selama tahun penelitian cenderung mengalami peningkatan. Nilai terendah ROE diperoleh pada tahun 2015 pada tahun tersebut perusahaan memperoleh laba terendah. Nilai ROE meningkat disebabkan adanya efisiensi kinerja dari PT Unilever Tbk dalam mengoptimalkan modal sendiri untuk menghasilkan laba bersih. Anne Erika Oktania dan Soedjono dalam penelitian nya menyatakan bahwa perhitungan ratarata Return On Equity Secara keseluruhan dari PT Telekomunikasi Indonesia Tbk tahun 2007-2011 mengalami kenaikan oleh karena itu PT Telekomunikasi Indonesia Tbk dari tahun 2007-2011 memiliki kinerja yang efisien karena Return On Equity dengan hasil perhitungan rasio keuangan perusahaan lebih besar atau diatas angka teoritis Equity. ${ }^{26}$ Hasil penelitian Dedi Suhendro dimana nilai ratarata rasio Return On Equity (ROE) PT Siantar Top Tbk dibawah rata-rata industri (time series) untuk kinerja keuangan dikatakan tidak baik dan tidak efisien, disebabkan karena kurang mengoptimalkan modal sendiri untuk menghasilkan laba bersih. ${ }^{27}$

Return on Asset (ROA) pada PT Unilever Tbk selama tahun 2010 sampai tahun 2015 secara berturut-turut 83,59\%, 113,13\%, 121,94\%, 125,80\%,120,89\% dan $121,22 \%$. Dapat dilihat bahwa nilai laba bersih perusahaan selama penelitian 
cenderung mengalami peningkatan dan mengakibatkan nilai ROA perusahaan juga meningkat. Naiknya nilai ROA dari tahun ke tahun menunjukkan bahwa kemampuan perusahaan untuk menghasilkan laba bersih yang maksimal dengan menggunakan aktivanya secara produktif semakin meningkat dengan demikian keuntungan yang diperoleh perusahaan berdasarkan investasi yang ditanamkan pada perusahaaan tersebut dalam kondisi rentabilitas ekonomis yang cukup baik. Penelitian yang dilakukan oleh Maikel Ch. Ottay dan Stanly W. Alexander hasil Return On Asset (ROA) mencerminkan kemampuan manajemen dalam memperoleh keuntungan (laba) secara keseluruhan berdasarkan perhitungan yang telah dilakukan maka diperoleh nilai ROA pada PT BPR Citra Dumoga Manado tahun 2009-2011 yang meningkat dari tahun ketahun. Nilai ROA yang terus meningkat ini menunjukkan bahwa PT BPR Citra Dumoga Manado tahun 20092011 mengalami peningkatan laba yang signifikan. ${ }^{28}$

\section{Kesimpulan}

Tingkat likuiditas PT Unilever Tbk mengalami penurunan secara keseluruhan. Hal ini diakibatkan perusahaan lebih memilih penggunaan dana dalam bentuk investasi demi menghasilkan laba yang optimal dibanding memenuhi kewajiban jangka pendek. Current ratio PT Unilever Tbk cenderung mengalami penurunan yang menandakan keadaan likuiditas perusahaan kurang baik. Quick ratio PT Unilever Tbk juga menurun sehingga dalam memenuhi kewajiban lancarnya belum dapat dikatakan baik.

Berdasarkan hasil analisis, rasio manajemen aset PT Unilever Tbk mengalami peningkatan secara keseluruhan. Hal ini disebabkan perusahaan sudah efisien dalam penggunaan asetnya untuk menciptakan penjualan. Semakin meningkatnya kemampuan perusahaan dalam melakukan penjualan maka semakin meningkatkan laba perusahaan.

Pada hasil analisis, rasio manajemen utang PT Unilever Tbk total hutang terhadap total aktiva sudah cukup baik karena perusahaan mampu menutup hutangnya melalui modal sendiri dan PT Unilever Tbk telah mampu menutupi beban bunga dengan dana yang dimilikinya. 
Rasio profitabilitas PT Unilever Tbk berdasarkan hasil analisis dapat disimpulkan menunjukkan kinerja perusahaan yang kurang baik karena laba bersih dari setiap penjualan yang diperoleh perusahaan dari tahun ketahun semakin menurun. Kurang efisiensinya kinerja dari PT Unilever Tbk dalam mengoptimalkan modal sendiri untuk menghasilkan laba bersih tetapi menggunakan aktivanya secara produktif semakin meningkat dengan demikian keuntungan yang diperoleh perusahaan berdasarkan investasi yang ditanamkan pada perusahaaan tersebut dalam kondisi rentabilitas ekonomis yang cukup baik.

Pada hasil penelitian ini, penulis menyarankan agar PT Unilever Tbk sebaiknya meningkatkan aktiva lancarnya dengan memperbanyak penggunaan dananya ataupun melalui penjualan aktiva tetap sehingga rasio likuiditas perusahaan semakin naik dari tahun ke tahun. PT Unilever Tbk juga sebaiknya mengurangi pinjaman dana dari pihak lain, karena semakin tinggi hutang perusahaan mana resiko kebangkrutan perusahaan juga semakin tinggi. Selain itu perusahaan juga sebaiknya lebih meningkatkan operasionalnya serta penggunaan dananya.

Penulis juga menyarankan untuk PT Unilever Tbk akan lebih baik lagi bila pihak manajer lebih memperhatikan dalam pengelolaan operasionalnya (khususnya aktiva lancar ataupun aktiva tetap seimbang dengan penjualan yang menguntungkan agar kinerja perusahaan pada periode tahun yang akan datang menunjukkan peningkatan lagi. Dan juga sebaiknya perusahaan senantiasa melakukan analisis rasio-rasio keuangan secara periodik demi mengetahui sejauh mana kinerja perusahaan yang telah dilakukan serta sebagai pertimbangan manajemen dalam mengambil kebijakan pada tahun-tahun berikutnya.

Sehubungan dengan keterbatasan-keterbatasan yang dimiliki penulis, penelitian ini jauh masih memiliki kelemahan-kelemahan dan belum dapat mengungkapkan semua rasio keuangan yang ada pada PT Unilever Tbk, maka penulis berharap peneliti lain dapat melanjutkan penelitian ini.

\section{Catatan}


${ }^{1}$ Riswan, Yolanda Fatrecia Kesuma. Analisis Laporan Keuangan Sebagai Dasar dalam Penilaian Kinerja Keuangan PT. Budi Satria Wahana Motor, Jurnal Akuntansi \& Keuangan. Vol. 5, No. 1, Maret 2014. h. 94.

2 Hendry Andres Maith. Analisis Laporan Keuangan dalam Mengukur Kinerja Keuangan Pada PT Hanjaya Mandala Sampoerna Tbk. Jurnal EMBA. Vol.1 No.3 September 2013. ISSN 2303-1174. h. 620.

${ }^{3}$ Recly Bima Rhamadana, Triyonowati. Analisis Rasio Keuangan untuk Menilain Kinerja Keuangan pada PT H.M Sampoerna Tbk. Jurnal Ilmu dan Riset Manajemen : Volume 5, Nomor 7 Juli 2016. ISSN : 2461-0593. h.3.

${ }^{4}$ Mutiara Nur'Rahmah, Euis Komariah, Analisis Laporan Keuangan dalam Menilai Kinerja Keuangan Industri Semen yang Terdaftar di BEI (Studi Kasus PT Indocement Tunggal Prakarsa TBK). Jurnal Online Insan Akuntan. Vol.1, No.1, Juni 2016. E-ISSN: 2528-0163. h.45. 2011.

${ }^{5}$ Ikatan Akuntan Indonesia. Pernyataan Standar Akuntansi Keuangan (PSAK). Jakarta

\footnotetext{
${ }^{6}$ Caecilia Sri Haryanti. Analisis Perbandingan Laporan Keuangan untuk Menilai Kinerja Keuangan pada Perusahaan Telekomunikasi (Studi Kasus BEI). Serat Acitya - Jurnal Ilmiah UNTAG Semarang 2014. h. 63
}

${ }^{7}$ Ibnu Sutomo. Analisis Rasio Profitabilitas untuk Menilai Kinerja Keuangan pada PT Niagaraya Kreasi Lestari Banjarbaru. KINDAI Vol 10 No. 4 Oktober-Desember 2014. h. 297

${ }^{8}$ Grace Monica Nuruwael, Sonang Sitohang. Analisis Rasio Keuangan Sebagai Alat untuk Menilai Kinerja Keuangan PT International Nickel Corporation Tbk. Jurnal Ilmu \& Riset Manajemen Vol. 2 No. 1 2013. h.10

${ }^{9}$ Horne, James C Van, John M Wachowicz, Jr. Prinsip-prinsip Manajemen Keuangan .edisi 13. (Jakarta. Salemba Empat. 2012)

${ }^{10}$ Niki Lukviarman. Dasar-Dasar Manajemen Keuangan. (Padang: Andalas University Press 2006)

${ }^{11}$ Brigham F. Eugene, Houston, Joel. Dasar - Dasar Manajemen Keuangan :Assetials Of Financial Management. (Jakarta. Salemba Empat 2010)

12 PT Unilever Tbk diakses pada laman http://www.unilevertbk.com

13 Bursa Efek Indonesia diakses pada laman http://www.idx.co.id

14 Anang Candra Wahyudi. Analisis Laporan Keuangan untuk Mengukur Kinerja Keuangan pada Perusahaan yang Go Public di Bursa Efek Indonesia (Studi Kasus pada PT Unilever Indonesia Periode 2006 - 2010). (Skripsi, Universitas Muhammadiyah Surakarta 2012). h.7.

${ }^{15}$ Anne Erika Oktania, Soedjono. Analisis Profitabilitas dan Likuiditas dalam Menilai Kinerja Keuangan dada PT Telekomunikasi Indonesia Tbk. Jurnal Ilmu \& Riset Manajemen. Vol. 2 No. 3 tahun 2013. h.13.

16 Yuli Orniati. Laporan Keuangan sebagai Alat untuk Menilai Kinerja Keuangan. Jurnal Ekonomi \& Bisnis. Tahun 14. Nomor 3. Nopember 2009. ISSN 0853-7283. h. 211.

17 Riswan, Yolanda Fatrecia Kesuma. Analisis Laporan... h.113

${ }^{18}$ Recly Bima Rhamadana, Triyonowati. Analisis Rasio.....h.14 
${ }^{19}$ Moch Ainul Yaqin, Sri Utiyati. Analisis Kinerja Keuangan pada Perusahaan Semen yang Terdaftar di Bursa Efek Indonesia. Jurnal Ilmu \& Riset Manajemen. Vol. 3 No. 7. 2014. h. 10.

${ }^{20}$ Anita Aprilia, Lailatul Amanah. Analisis Rasio Keuangan untuk Mengukur Kinerja Keuangan pada Koperasi Dhaya Harta Jombang. Jurnal Ilmu \& Riset Akuntansi Vol. 3 No. 4. 2014. h. 10.

${ }^{21}$ Caecilia Sri Haryanti. Analisis Perbandingan............ h. 66

${ }^{22}$ Anita Aprilia, Lailatul Amanah. Analisis Rasio Keuangan......h.11

${ }^{23}$ Yuli Orniati. Laporan Keuangan sebagai Alat. h. 210 .

${ }^{24}$ Ingrid Emilia Turang. Analisis Rasio Keuangan sebagai Alat Penilaian untuk Mengukur Kinerja Keuangan pada PT Bank Tabungan Pensiunan Nasional Tbk periode tahun 2010-2012. Jurnal Acta Diurna.Universitas Sam Ratulangi, Manado. Vol II No 3 tahun 2013.h. 13.

${ }^{25}$ Dedi Suhendro. Analisis Profitabilitas dan Likuiditas untuk Menilai Kinerja Keuangan pada PT Siantar Top Tbk. Human Falah. Jurnal Ekonomi dan Bisnis Islam; Volume 4. No. 2 Juli - Desember 2017. h. 229

${ }^{26}$ Anne Erika Oktania, Soedjono. Analisis Profitabilitas. h. 14

${ }^{27}$ Dedi Suhendro. Analisis Profitabilitas .h. 231

${ }^{28}$ Maikel Ch. Ottay, Stanly W. Alexander. Analisis Laporan Keuangan untuk Menilai Kinerja Keuangan pada PT. BPR Citra Dumoga Manado. Jurnal EMBA. Vol. 3 No.1 Maret 2015, ISSN 2303-1174. h.931

\section{Daftar Pustaka}

Anita Aprilia, Lailatul Amanah. Analisis Rasio Keuangan untuk Mengukur Kinerja Keuangan pada Koperasi Dhaya Harta Jombang. Jurnal Ilmu \& Riset Akuntansi Vol. 3 No. 4. 2014.

Anne Erika Oktania, Soedjono. Analisis Profitabilitas dan Likuiditas dalam Menilai Kinerja Keuangan dada PT Telekomunikasi Indonesia Tbk. Jurnal Ilmu \& Riset Manajemen. Vol. 2 No. 3 tahun 2013.

Brigham F. Eugene dan Houston, Joel. Dasar - Dasar Manajemen Keuangan :Assetials Of Financial Management. (Jakarta. Salemba Empat 2010)

\section{Bursa Efek Indonesia. http://www.idx.co.id}

Grace Monica Nuruwael \& Sonang Sitohang. Analisis Rasio Keuangan Sebagai Alat untuk Menilai Kinerja Keuangan PT International Nickel Corporation Tbk. Jurnal Ilmu \& Riset Manajemen Vol. 2 No. 12013.

Haryanti, Caecilia Sri. Analisis Perbandingan Laporan Keuangan untuk Menilai Kinerja Keuangan pada Perusahaan Telekomunikasi (Studi Kasus BEI). Serat Acitya - Jurnal Ilmiah UNTAG Semarang 2014. 
Analisis Penilaian Kinerja Keuangan Perusahaan Menggunakan Rasio 505

Keuangan Pada PT Unilever Indonesia Tbk Yang Terdaftar

Di Bursa Efek Indonesia (Dedi Suhendro)

Horne, James C Van, John M Wachowicz, Jr. Prinsip-prinsip Manajemen Keuangan .edisi 13. (Jakarta. Salemba Empat. 2012)

Ikatan Akuntan Indonesia. Pernyataan Standar Akuntansi Keuangan (PSAK). Jakarta 2011.

Lukviarman, Niki. Dasar-Dasar Manajemen Keuangan. (Padang: Andalas University Press 2006)

Maikel Ch. Ottay, Stanly W. Alexander. Analisis Laporan Keuangan untuk Menilai Kinerja Keuangan pada PT. BPR Citra Dumoga Manado. Jurnal EMBA. Vol. 3 No.1 Maret 2015, ISSN 2303-1174.

Maith, Hendry Andres. Analisis Laporan Keuangan dalam Mengukur Kinerja Keuangan Pada PT Hanjaya Mandala Sampoerna Tbk. Jurnal EMBA. Vol.1 No.3 September 2013. ISSN 2303-1174.

Moch Ainul Yaqin, Sri Utiyati. Analisis Kinerja Keuangan pada Perusahaan Semen yang Terdaftar di Bursa Efek Indonesia. Jurnal Ilmu \& Riset Manajemen. Vol. 3 No. 7. 2014.

Mutiara Nur'Rahmah, Euis Komariah, Analisis Laporan Keuangan dalam Menilai Kinerja Keuangan Industri Semen yang Terdaftar di BEI (Studi Kasus PT Indocement Tunggal Prakarsa TBK). Jurnal Online Insan Akuntan. Vol.1, No.1, Juni 2016. E-ISSN: 2528-0163.

Orniati, Yuli. Laporan Keuangan sebagai Alat untuk Menilai Kinerja Keuangan. Jurnal Ekonomi \& Bisnis. Tahun 14. Nomor 3. Nopember 2009. ISSN 0853-7283.

PT Unilever Tbk. http://www.unilevertbk.com

Recly Bima Rhamadana, Triyonowati. Analisis Rasio Keuangan untuk Menilain Kinerja Keuangan pada PT H.M Sampoerna Tbk. Jurnal Ilmu dan Riset Manajemen : Volume 5, Nomor 7 Juli 2016. ISSN : 2461-0593.

Riswan, Yolanda Fatrecia Kesuma. Analisis Laporan Keuangan Sebagai Dasar dalam Penilaian Kinerja Keuangan PT. Budi Satria Wahana Motor, Jurnal Akuntansi \& Keuangan. Vol. 5, No. 1, Maret 2014.

Suhendro, Dedi. (2017). Analisis Profitabilitas dan Likuiditas Untuk Menilai Kinerja Keuangan Pada Pt Siantar Top Tbk. Human Falah, 4 (2), 218235 .

Sutomo, Ibnu. Analisis Rasio Profitabilitas untuk Menilai Kinerja Keuangan pada PT Niagaraya Kreasi Lestari Banjarbaru. KINDAI Vol 10 No. 4 OktoberDesember 2014. 
506 | At-Tawassuth, Vol. III, No. 1, 2018: 482- 506

Turang, Ingrid Emilia. Analisis Rasio Keuangan sebagai Alat Penilaian untuk Mengukur Kinerja Keuangan pada PT Bank Tabungan Pensiunan Nasional Tbk periode tahun 2010-2012. Jurnal Acta Diurna.Universitas Sam Ratulangi, Manado. Vol II No 3 tahun 2013.

Wahyudi, Anang Candra. Analisis Laporan Keuangan untuk Mengukur Kinerja Keuangan pada Perusahaan yang Go Public di Bursa Efek Indonesia (Studi Kasus pada PT Unilever Indonesia Periode 2006 - 2010). (Skripsi, Universitas Muhammadiyah Surakarta 2012). 